\title{
INTERNATIONALIZATION OF ISLAMIC EDUCATION INSTITUTIONAL CHARACTERS THROUGH THE ENGLISH ACCULTURATION STRATEGY
} Isa Anshori ${ }^{*}$, Elly Elvina Sahara ${ }^{2}$

${ }^{1 *}$ Assoc. Prof., The State Islamic University Sunan Ampel, Surabaya, Indonesia; ${ }^{2}$ English teacher, Master Candidates, Masters in Islamic Education Management, Muhammadiyah University Sidoarjo, Indonesia. Email: ${ }^{*}$ isaanshori67@gmail.com, ${ }^{2}$ ellyelvinasahara@gmail.com Article History: Received on $25^{\text {th }}$ March 2020, Revised on $10^{\text {th }}$ September 2020, Published on $20^{\text {th }}$ September 2020

Abstract

Purpose of the study: To explore the effectiveness of the English-speaking acculturation strategy in improving the English ability of school members so that they can internationalize the character of Islamic educational institutions.

Methodology: Using a qualitative phenomenological approach, with observation, interview, and documentation as data collection techniques, and reduction, display, and conclusion become the stages of data analysis. The research sample of 255 teachers, employees, and students was determined purposively at Taman Islam Middle School, Sidoarjo, Indonesia.

Main Findings: This study found that an English-speaking acculturation strategy was effective in improving the English-speaking ability of school residents (up 4.63 from target 3) so that the internationalization of the character of Islamic education institutions, innovative, was formed.

Applications of this study: This study is useful to improve the quality and become a prototype of the actualization of the character of international education institutions, through the strategy of acculturation in English, especially in Islamic schools.

Novelty: This study creates the basis and prototype for the actualization of international standard Islamic education institutions, through an English-speaking acculturation strategy. The principal's policy requires the English to inspire its representatives, together formulate and realize an English acculturation program; inspire teachers, staff, and students to carry out various English-speaking acculturation activities both inside and outside the school. Cultivation of English becomes more effective. The English skills of teachers, employees, and students from the aspects of listening, grammar, reading, writing, and speaking have increased, so that the internationalization of Islamic institutional character, in the form of integrity, professionalism, innovation, responsibility, and example, can be formed more quickly.

Keywords: Internationalization, Effectiveness, Acculturation Strategy, English, Institutional Character, Islamic Schools.

\section{INTRODUCTION}

International standard schools is a label that has recently sprung up in various Indonesian educational institutions. International Label indicates the strength of competition, especially with the permission of foreign parties to establish educational institutions in Indonesia. The cost of foreign school fees is indeed much higher, but received a positive response from the community, especially from upper economic circles. Such a condition, if it continues, could threaten the sustainability of private schools, especially Islamic educational institutions, where the majority of the population is Muslim.

Labeling of international schools carried out by Islamic schools that have been and are ongoing until now, as an effort to compare (Irwan \& Mahmud, 2017; Khan \& Ebner, 2017), shows the quality of Islamic schools - convincing the community that the quality of Islamic schools that have long been established in the country is far better compared to immigrant schools. Through international branding like this, it is expected that the community, especially Muslim communities, have confidence in Islamic educational institutions so that it becomes the first choice in sending their children to school.

The problem is, not all Islamic educational institutions can compare international standard schools. There are still those who provide international labeling, only costs that are internationally priced, while the quality of services, processes, and graduates do not yet reflect international standards. Whereas in many parts of the world, a global international education has emerged by offering quality education, lower costs, in a safe place, closer to home (Johnson, 2020). The media used for publication also sometimes still hide real information (Kurnia, Othman, Firmansyah \& Kuswarno, 2020). As a result, community confidence has declined, so that its existence and sustainability is questioned.

This is where the importance of the internationalization of Islamic schools must be accompanied by the establishment of a progressive character of Islamic education. Innovative characters with Islamic personalities who are ready to collaborate and compete with various international education institutions must be formed in Islamic educational institutions. Consequently, Islamic schools must be able to choose and implement the right strategy.

Previous research shows that the internationalization of Islamic educational institutions requires "good governance, aligning vision, mission, targets, quality policy, and strategic plans, there must be a special institution international, human resource development and decision-making systems that are fast and not rigid "(Binangkit \& Siregar,2020: 131). The school must have an international curriculum design whose contents, processes, and assessments are clear, precise, 
comprehensive, and oriented to the demands of the global market (Heriansyah, 2014). And also be able to prepare students in the era of demographic bonuses (Chudzaifah, 2018). Participate actively, holistically, and comprehensively in the Islamic industrialization agenda (Qomaro, 2019). Zuhdi's research (2018) shows that the internationalization of education has a positive impact on Islamic educational institutions. Nursalam's research (2020) proves the use of a glocal vision curriculum to foster student attitudes that can affect aspects of internationalization of higher education.

Nurhamidi (2015) found the importance of varied communication strategies in developing quality educational institutions. In contrast to Surachman and Wiksana (2019), his research found that communication did not become a major factor in the administration of schools.

Karolina's (2017) research highlighted the reconstruction of Islamic primary and secondary education through internalization of the values of the Qur'an. Fawaid (2017) found the importance of strategies for strengthening character education through disciplining school discipline. Yani et al. (2017) show the success of the character-building strategy through parenting. Rizal and Munip (2017), provides a solution to the character formation strategy in the classroom through intracuricular and extracurricular activities. Hidayatulla et al. (2017) found the effectiveness of character building strategies through learning strategies and innovative learning media. Evananda et al. (2018) found the character values in Dolan School. Halmar (2018) found the importance of raising awareness of all school members in the formation of character in the school.

Hariyanto and Jahibab (2019) demonstrated the strategy of strengthening character in schools through harmonization of the heart, if the taste, thought though, and physical sports. Baroroh (2018) found the implementation of multicultural education values in the formation of a religious character. Latupapua et al. (2019) found effective stories in shaping students' anti-corruption characters. Sabri (2019) shows the effectiveness of Durham tahfidz in forming the character of children.

Unlike the various studies, which place the teacher as the main actor for the formation of character in schools. Widodo (2018) shows precisely the principal who has the biggest role in character building in schools. While Basyit's research $\underline{(2019)}$ specifically highlights the driving factors for the emergence of elite schools in Indonesia, namely internal and external factors. When examined, the various studies are more focused on the process of shaping the internal character of schools, Basyit's latest research only analyzes the factors causing the emergence of various elite schools.

The novelty of this research, when compared with previous researches, lies in the strategy of shaping the character of Islamic educational institutions to become schools of international standard quality, through the strategy of acculturation in English.

Shaping the character of international standard Islamic education institutions by emphasizing the habituation of Islamic values, through the acculturation of English in the school environment. This was done so that Islamic schools could develop and be able to take part in the international arena. The process in institutions, education, and learning has the character of Islam of international quality, the output also has the character of international quality Islam.

This research was conducted at an Islamic high school located in the second largest urban suburb of Indonesia. The school is based on Islam, has the motto "The Islamic Character School" which also includes a superior class program, International Class Orientation (ICO), and has a high concentration in creating an international Islamic school.

This research seeks to explore the effectiveness of the English-speaking acculturation strategy in shaping the character of international standard Islamic education institutions, aiming to answer the questions: 1. How is the English-speaking acculturation strategy implemented in the context of internationalizing the character of Islamic educational institutions? 2. How is the effectiveness of the English acculturation strategy in improving the English language skills of school citizens so that it can shape the character of international standard Islamic education institutions?

\section{LITERATURE REVIEW}

The strategy is a careful plan regarding activities to achieve specific goals (Ali, 2005). As a whole approach related to the implementation of ideas, planning, and execution of activity within a certain period (Badudu \& Zain, 1996). In this case, there are three stages of strategy, namely the formulation, implementation, and evaluation (David, 2006).

Institutional character is a characteristic of an institution that is composed of behavioral patterns to achieve a goal. The intended institutional character is the internationalization of Educational institutions which are based on the basic values of Islamic teachings. Being a character of integrity, professionalism, innovation, responsibility, and example as taught by Islam.

Acculturation is a process of all social culture into a strong custom or institution (Ali, 2005). Communication has the meaning of a person's process, some people, groups, organizations, and society create, and use the information to connect with the environment and other people (Ali, 2005). Communication has components: who the communicator is, what message it states, what media it uses, who the communicant is, and what effect it expects (Effendi, 2014). Cultivation in English means getting English used as a communication tool by all citizens in carrying out various school activities. 
Schools that are already cultured in English are more likely to collaborate with other countries (Vranes \& Markovic, 2017). Can gather students from various countries, encourage communication and exchange of information using the same language (Cintra, da Silva, \& Furnival, 2020). In this way, professionalism, theoretical-scientific abilities, and social and cultural values can be better formed. (Badke, Barbieri, \& Martorell-Poveda, 2018).

Until now, the acculturation of English in various Muslim worlds is still experiencing difficulties, because it is perceived as a foreign language (Al-Ahdal \& Al-Qunayeer, 2020), as is the case in Indonesia (Karim, Sulistyo, Rachmajanti, \& Suryati, 2020). The responses shown by English teachers in each school were also different, resulting in different goals, materials, and learning methods (Yusra \& Lestari, 2020). Also, feeling ashamed to speak English for fear of being wrong, it is better to be quiet when invited to speak English, late in responding to questions, unclear responses, and switch to languages other than English (Vallente, 2020).

Other research shows, there is no correlation between the emotional intelligence nature of teachers with students' understanding of the jargon learned, but there is a correlation of two positive traits namely emotionality and socialization (Azar, Yi, \& Azhar, 2020). Likewise, there is no correlation between English language proficiency with students' academic performance (Gheyathaldin \& Shishakly, 2020), but at least this English proficiency has a contribution for students to deepen various English references. So that their insights are broader.

The results of Rajab and Azeebaree's research (2020) found that the effectiveness of the culture of English could occur if students were able to read English well, were integrated with class activities, and the lessons were prepared every day. According to the research of Elfiondri, Usman, Mustofa, and Putra (2020), reading comprehension is the most difficult part of English, therefore providing more time is needed. Whereas James and Bulusan's research (2020) found, the application of metacognitive strategies plays an important role in reading comprehension, but the results are not always the same for every student. To overcome all that needed the right strategy.

The principal's policy requires all English residents to speak English for the school as an alternative strategy. So that the culture can take place. Encourage all school components to be able to create situations and conditions of culture in English, and dare to speak English. The strategy is implemented through steps to get to know the audience, compose messages, set methods, then use the media and provide various technological facilities, supported by the creation of situations and conditions in speaking English, as such that can encourage the acculturation of the English language, so that the internationalization of the character of Islamic educational institutions can form.

The principal's policy of cultivating English is very helpful for English teachers in carrying out their duties as learners. For this reason, the enthusiasm of the teacher must be demonstrated. Passion is very important for effective and highquality teaching. A passionate teacher always inspires students in the classroom and outside the classroom, making learning enthusiastic (Khan, 2020). English teachers must also be able to be positive about the occurrence of mixing English codes with local languages (Al-Ahdal, 2020). This openness makes the culture of English more effective. The presence of native English speaking teachers is also very important, effective in fostering student learning motivation, and has pedagogical, psychological, linguistic, and language development implications (Darmanto, 2020).

In the context of today's life, the use of technology in learning English is very effective for the acculturation of English. The principal's commitment is very important for the provision of technology and enhancing the technological competence of all these teachers, without gender bias. The results of previous studies show the teacher has a positive attitude in implementing online independent learning, the constraints on task instruction are still limited, technical problems, and communication during learning takes place (Masrizal, Fata, \& Erdiana, 2020). There is no gender gap in terms of attitudes and competencies in the use of English learning, but there is a significant positive and linear relationship between attitude and technological competence (Javier, 2020). For teachers who have technological competence to be positive about the use of technology in learning, and vice versa.

Provision of technology and improvement of technological capabilities in learning English, encourage the acceleration of English-language culture for all school residents. Become part of the evidence of the principal's commitment to internationalizing the character of the institution.

The Strategy of Institutional Character Building of Islamic Education through the acculturation of English is intended as steps taken in the process of forming the character of international standard Islamic education institutions through the process of acculturating communication using English by all teachers, employees, students, and leaders in daily life through various school programs and activities.

The formation of the institutional character of international Islamic education must be accompanied by the strengthening of character education in schools (Anshori,2017). Based on the school curriculum structure, namely: class-based character education, school-based character education, and community-based character education (Anshori, 2018).

An important point in efforts to shape the institutional character of Islamic education is to emphasize the habituation of Islamic values in the daily life of the school. One of the intended habits is in the form of acculturation in English in the school environment. This is intended because English communication skills are needed to be able to compete in the international arena. Also, the acculturation of English has been included in one of the five ministry work cultures, 
namely innovation. Aiming at perfect existing ones and creating new things better. The other four are integrity, professionalism, responsibility, and example.

Work culture is the values that become the nature, habits, and supporter that are cultivated in a group and reflected in attitudes, behavior, ideas, opinions, views, and actions that manifest as work or work (Anshori,2018).

Therefore to facilitate the formation of institutional character of Islamic education through the acculturation of English communication there needs to be an appropriate strategy so that the internationalization of schools can be achieved.

\section{RESEARCH METHODOLOGY}

\section{Research Design}

The type of research used is qualitative with a phenomenological approach. That produces descriptive data in the form of written and oral form predetermined sources, as well as various behaviors that are observed and can be used as research data (Moleong, 2011). Serves to understand the conditions and situations and the reality faced by a person or organization.

Phenomenology, in addition to interpreting from what appears by the five senses also unpacks the meaning behind what appears. Not only describes the phenomenon of ongoing education but also understands what appears. The questions raised by researchers are not only how, but also why (Anshori, 2018). Tries to understand the experiences and phenomena that occur on the subject of research (Muhajir, 1996: 104).

The phenomenological approach was chosen because researchers saw and felt directly the acculturation of English in schools. The researcher not only obtained answers to how but also why the acculturation of English was chosen as a strategy for shaping the character of Islamic institutions in schools.

\section{Sampling}

The study was conducted at SMP Muhammadiyah 2 Taman, a second largest suburban Islamic school in Indonesia, starting July 1, 2019, to May 30, 2020. The school has 20 study groups, 606 students, six study groups in class VII, each with seven study groups in classes VIII and IX, and there are three program choices, namely Regular Class, Tahfidz Class, and International Class Orientation. The learning process is managed by 44 teachers and served by 12 education staff.

The research subjects were determined purposively, consisting of teachers, employees, and students. This school was chosen, because it has a special program class namely International Class Orientation, using the English Proficiency Program curriculum in collaboration with ACT Australia. There are also regular classes and Tahfidz. Another consideration, because it has a high concentration in shaping the character of Islamic institutions, following the motto "The Islamic Character School".

Table 1: Research subject

\begin{tabular}{lllllllll}
\hline \multirow{2}{*}{ No } & Subject & \multicolumn{2}{c}{ Gender } & \multicolumn{2}{c}{ Total } & \multicolumn{2}{c}{ Age } & \multicolumn{2}{c}{ Amount } \\
\cline { 3 - 4 } & & Male & Female & & $\mathbf{1 3 - 1 5}$ & $\mathbf{1 9 - 4 0}$ & $\mathbf{4 1 - 6 0}$ & \\
\hline 1 & Regular Students & 61 & 40 & 101 & 101 & - & - & 101 \\
\hline 2 & Tahfidz students & 14 & 13 & 27 & 27 & - & - & 27 \\
\hline 3 & ICO students & 39 & 32 & 71 & 71 & - & - & 71 \\
\hline 4 & Teacher & 21 & 23 & 44 & - & 29 & 15 & 44 \\
\hline 5 & Employee & 6 & 6 & 12 & - & 10 & 2 & 12 \\
\hline Total & 141 & 114 & 255 & 199 & 39 & 17 & 255 \\
\hline
\end{tabular}

The type of data collected is qualitative and quantitative, obtained from the main sources, including words and actions, the additional data, such as documents and others (Moleong, 2011). Qualitative data in the form of various programs and activities in English-speaking culture in schools, the achievement of indicators of the character of integrity, professionalism, innovation, responsibility, and role models in Islamic educational institutions. Quantitative data are in the form of English language proficiency scores of students, teachers, and staff before and after English-language acculturation strategies are established. These abilities include listening, speaking, reading, writing, and grammar. To understand the effectiveness of English-speaking culture in shaping the character of Islamic educational institutions, an analysis of the condition of the character of school residents was conducted before and after the stipulation of the English language obligation policy. Also supported by quantitative data in the form of student, teacher, and employee attendance before and during the English-language policy.

\section{Data-Collection Procedures}

The researcher uses participant observation, in-depth interviews, and documentation to obtain complete data. Observe phenomena that occur at school, get involved directly, record attitudes, behaviors, and events at school, inside, and outside the classroom, the atmosphere of learning, and outside of learning, both official and informal. All of this was 
done to understand the character integrity, professionalism, innovation, responsibility, and neutrality, as well as strategies for shaping the character of Islamic educational institutions through English-speaking culture.

Researchers then conducted interviews, initially of a general nature then in-depth and focused on leaders, teachers, employees, and students related to the acculturation of English, as well as its effect on school internationalization.

While the documentation is used to complement the data obtained from observations and interviews. The documents used are mainly related to the results of English language proficiency tests (listening, grammar, reading, writing, speaking) teachers, staff, and students before and after the acculturation of English communication, to become an international standard school.

\section{Data-Analysis Techniques}

Researchers used the Miles and Huberman analysis technique models. Starting with data reduction, data display, and concluding (Moleang, 2011). Whereas for quantitative data in the form of English language proficiency the researcher uses descriptive quantitative analysis through tabulation and graphic designation. To obtain the accuracy and credibility of the collected data, researchers conducted triangulation by checking back with data from other sources (Moleong, 2011), followed by discussions with the research team.

\section{RESULTS AND DISCUSSION}

\section{Strategies for Forming the Characters of International Institution Islamic Education}

Acculturation in English is established in schools, as a strategy to form an institutional Islamic character, to make the school an international standard.

Acculturation is a social process of forming culture into a standard institution. English-speaking culture is a sociocultural process that makes communication institutions, which must be obeyed and carried out by all components of the school, accompanied by strict sanctions for those who do not obey. This strict sanction is what makes all components of the school obey. Initially, obedience was forced, the darkness became a recognized habit.

The principal decided to make English a habit of communication, even if only one day a week, as a first step. Also, to support the habituation of English, also scheduled regularly, events that support habituation in English. This is all done because the character grows from habituation that is done.

Integrity, professionalism, innovation, responsibility, and example as taught by Islam are the main characters in Islamic educational institutions. These characters can be realized among others through the culture of good communication between school residents. So that it becomes a school culture.

English-speaking culture is used as a strategy to form the character of international standard Islamic education institutions, implemented through the steps of getting to know the audience, composing messages, setting methods, then using the media.

\section{Get to know the audience}

Knowing the audience is a communicator's effort to get to know the intended communicant. The principal as a communicator, held a meeting to socialize the launching of the English Proficiency Program class which has now turned into International Class Orientation.

The principal's meeting with the school community, besides socializing ICO, is also to get to know each other and know the response of the school community as the communicant. Meetings like this are important to align perceptions and interests so that effective communication is established. Communication becomes effective. If the communicator knows the communicant well.

\section{Composing Message}

In composing a message, the thing to do is to determine the theme and material. Cultivation of English in schools is to foster the character of Islamic educational institutions.

The material in acculturation in English in the form of development activities in English is associated with the values of Islamic teachings, as an Islamic educational institution.

Phenomena that occur in schools, such as tit for tat. The statement of the head "we must cultivate English speaking. So that our schools are of international standard". Encourage the deputy head of the curriculum to design several activities to develop a culture of English in the school environment.

The programs in the development of the culture of English communication as in table 2.

These various programs are carried out by schools as a strategy to shape the institutional character of Islamic education, through the acculturation of English. The theme presented is internationalization. The material presented is Islamic values that are packaged into a variety of English-speaking cultural programs in schools. 
Table 2: Development Program for Culture of English Communication in Schools

\begin{tabular}{ll}
\hline Program & Aim \\
\hline ACT Program Registration & Improve understanding in learning English \\
\hline English Friendship Camp & $\begin{array}{l}\text { Strengthen the sense of brotherhood with other classes and } \\
\text { train students' habits in using English in daily activities }\end{array}$ \\
\hline Mind Empowering & $\begin{array}{l}\text { Motivate children to be enthusiastic and more diligent in } \\
\text { learning English }\end{array}$ \\
\hline Students' Talent show & $\begin{array}{l}\text { Train Confidence in students to appear in public using } \\
\text { English }\end{array}$ \\
\hline English Day & $\begin{array}{l}\text { Practicing Cohesiveness and speaking using English through } \\
\text { some fun games }\end{array}$ \\
\hline Learning Through Native & Add English vocabulary and facilitate speaking English \\
\hline Watching Movie & Build insight through film \\
\hline ICO Competition & Improve skills in English \\
\hline Vocabulary Class & Enrich the vocabulary of English \\
\hline Speaking Class & Develop the ability to speak in English \\
\hline
\end{tabular}

\section{Establish the Method}

The effectiveness of English language acculturation, besides being determined by the stability of the message content adjusted to the communicant's condition, is also influenced by a varied method of delivery to the communicant. Theoretically, there are two methods of delivering messages, namely Repetition and Canalizing. But this school uses repetition, namely how to influence the audience by repeating the message conveyed. It means that the communicant always remembers and pays attention to the message delivered by the communicator.

There are several ways in which principals act as communicators in the repetition method, including the holding of monthly meetings that are usually held at the Regional Office of Muhammadiyah East Java, school coordination meetings, special meetings for English teachers. In this monthly meeting, the internationalization of the Muhammadiyah school is always conveyed through acculturation in English.

Through this repetition method, acculturation in English can be done by all school members, namely leaders, teachers, employees, and students. The message conveyed is related to the institutional character values of Islamic education, namely integrity, professionalism, innovation, example, and responsibility, in English.

\section{Media use}

To shape the institutional character of Islamic education, schools carry out direct English-language acculturation, face to face, both through coordination meetings and monthly routine meetings. Also through the media, which is a notice that reads thank for speaking English on Thursdays which is posted in several places such as the teacher's room, classroom, ICO corner, and Administrative room. All of this was done so that all school members were accustomed to speak English even if only for one day a week, but if it continues to be conducted, the culture of English can be realized.

Strategies for building the character of Islamic educational institutions through English language acculturation have been carried out in schools, ranging from getting to know the audience through coordinating meetings attended by all teachers and employees, compiling messages containing the theme and purpose of the message, namely internationalizing schools by acculturating English, establishing and using repetition method so that the public is always remembered and implemented, as well as the use of media by sticking notices in several places and face to face through meetings held.

\section{Strategy Effectiveness}

English speaking culture is an effective strategy, succeeding in shaping the institutional character of Islamic education in schools, reflected in the implementation of various school programs, namely:

\section{English language habit through one day program in English}

This program is carried out every Thursday, requiring all English-speaking school members to communicate, from the principal, teachers, employees, to students. In learning also using English, at least at the opening and closing. NonEnglish teachers are provided with modules that contain opening and closing in English, as well as simple instructions that are usually used by teachers in learning. This method was welcomed positively by the teacher. So that the teachers were the easiest to implement.

With this module, the program runs better and smoother. Modules compiled by the team were copied like a teacher and then given to the teachers to make it easier to run this English-speaking civilization program.

\section{English area procurement}

The English area in question is an area where all are required to speak English in communication, both teachers and students. This area is located in the ICO corner on the second floor. Through the English area, it is hoped that the 
internationalization of the character of Islamic education institutions will be formed, through the acculturation of English.

\section{Up-grading students through special events}

Special events are activities aimed at acculturating English. Several special events have been formulated by the deputy head of the curriculum and staff, including English Friendship Camp, English Fun Camp, Mind Empowering, Students Talent, ICO Competition, Learning Through Native, Watching Movie, English Camp in Pare, and also Summer Camp. Especially for ICO classes, there are additional hours of vocabulary classes and speaking classes. All events of these special events have different goals but the essence is the same as the culture of English in schools.

Special events, usually called summer camps, are held in Malaysia and Singapore. The goal is cross-culture so that students know cultures abroad and can create new experiences for students.

Similar to one day in English and English areas, these special events also have the same goal of forming the institutional character of Islamic education through the acculturation of English. This special event has been running for about 4 years, with renewal every year. It is hoped that with these special events, it will increasingly make the acculturation of the English language more developed.

\section{Stick the Notice}

Notice is an instruction posted in several rooms containing instructions for using English. Some of the spaces in question include the teacher's room, administration room, ICO class, and also the ICO corner.

Researchers found that notice turned out to make many changes in schools. Because notice is visible all the time, so everyone who sees immediately remembers and does it. This is one of the effective media in shaping the institutional character of Islamic education, through acculturation in English. Indirectly, everyone who sees the notice is told to do so. As a result, all teachers, students, and even employees are finally accustomed to speaking English, according to their abilities.

In real terms, the ability to speak English among students of teachers and employees increases, compared to before the stipulation of the English language obligation policy, as can be seen in the following figure.

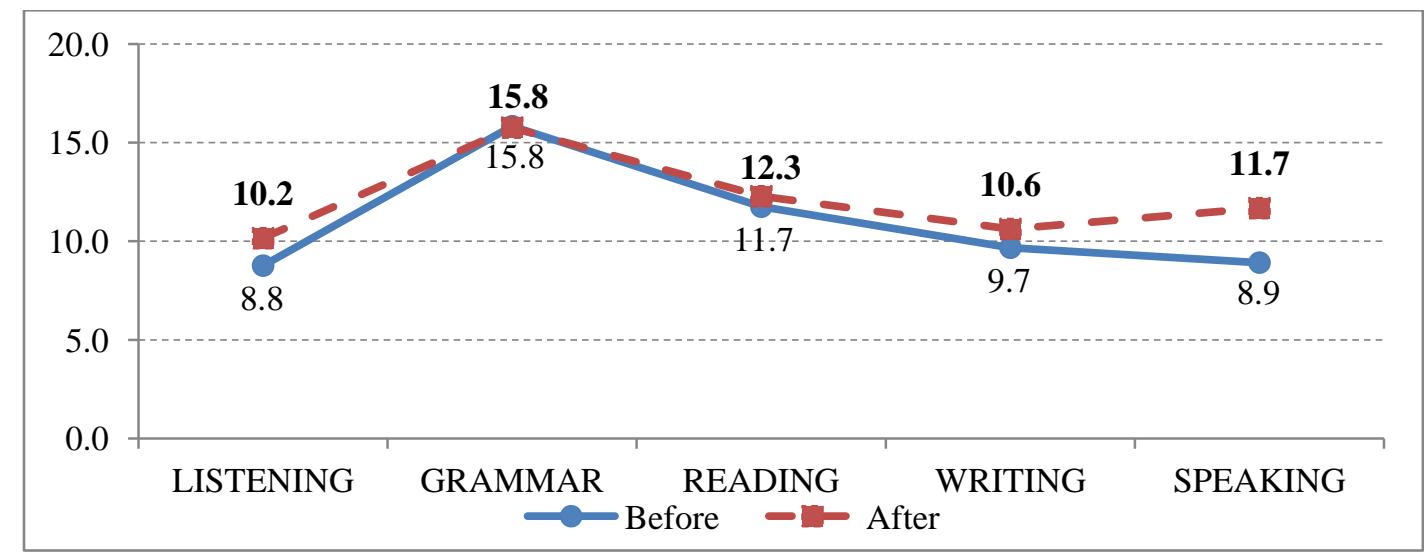

Figure 1: Increased English Skills in Regular Students

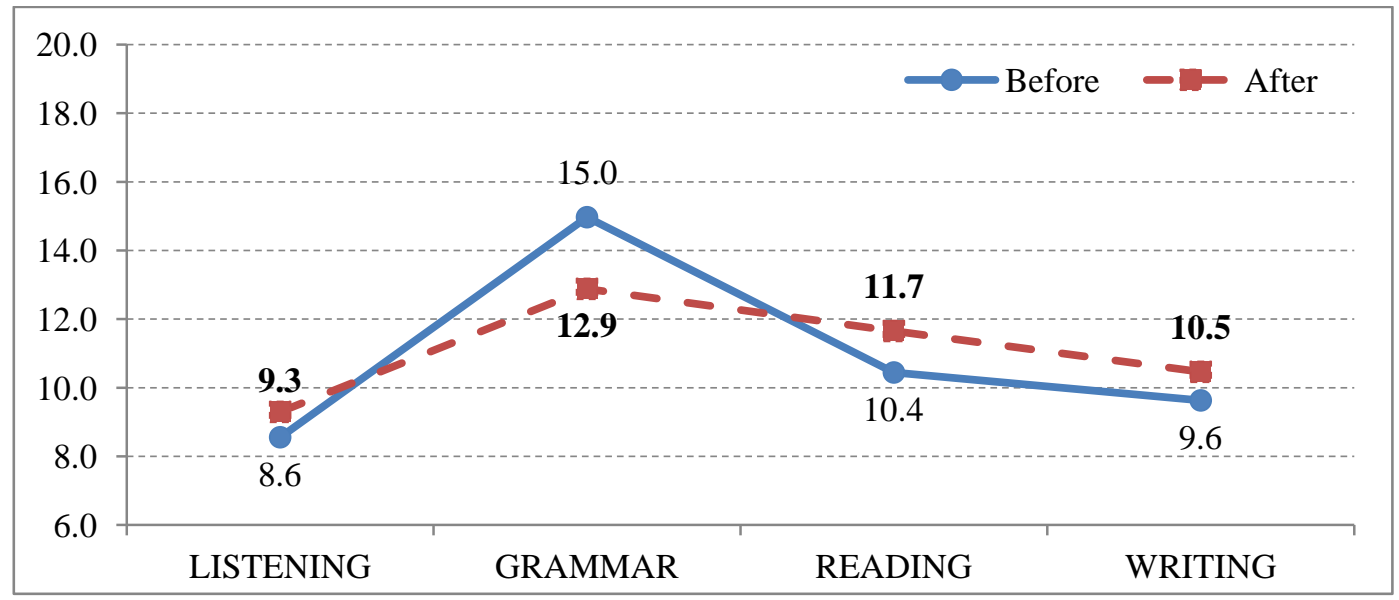

Figure 2: Increased English Skill in Tahfidz Students 


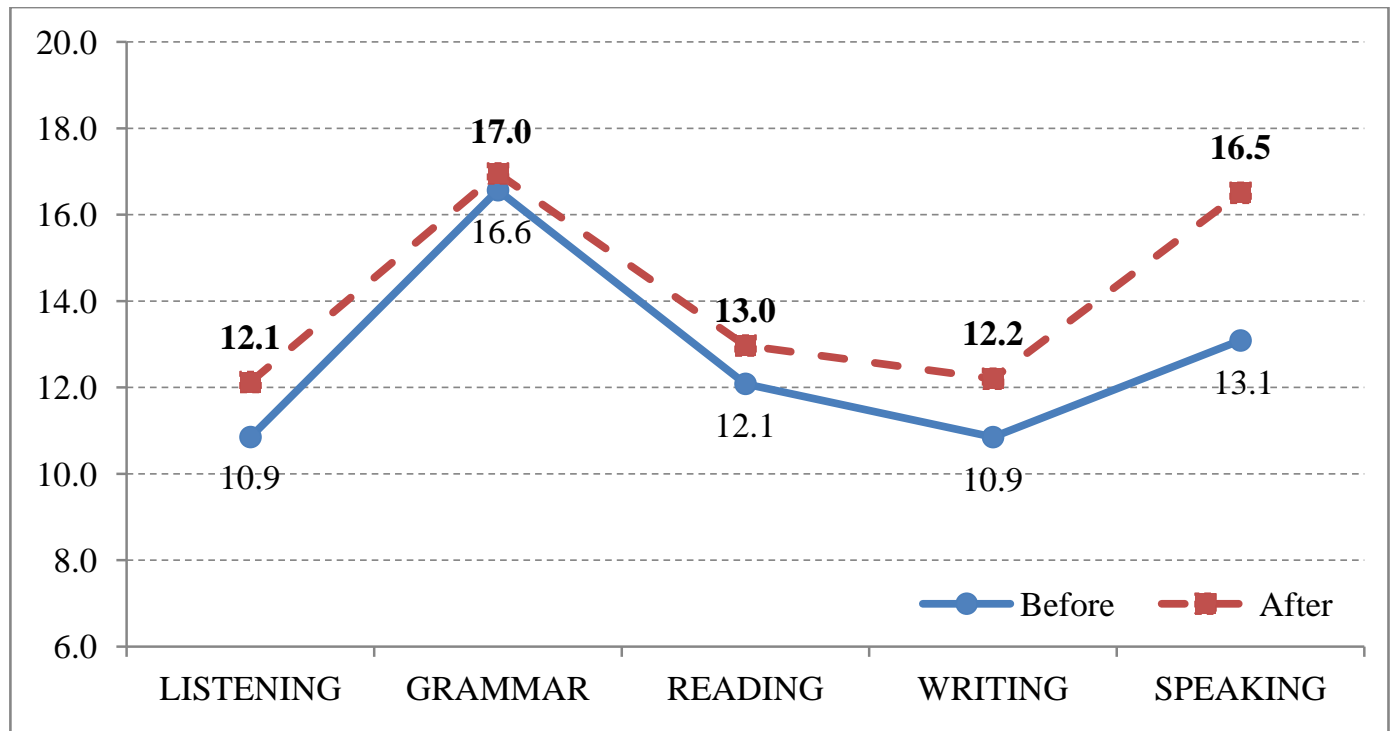

Figure 3: Increased English Skill in ICO Students

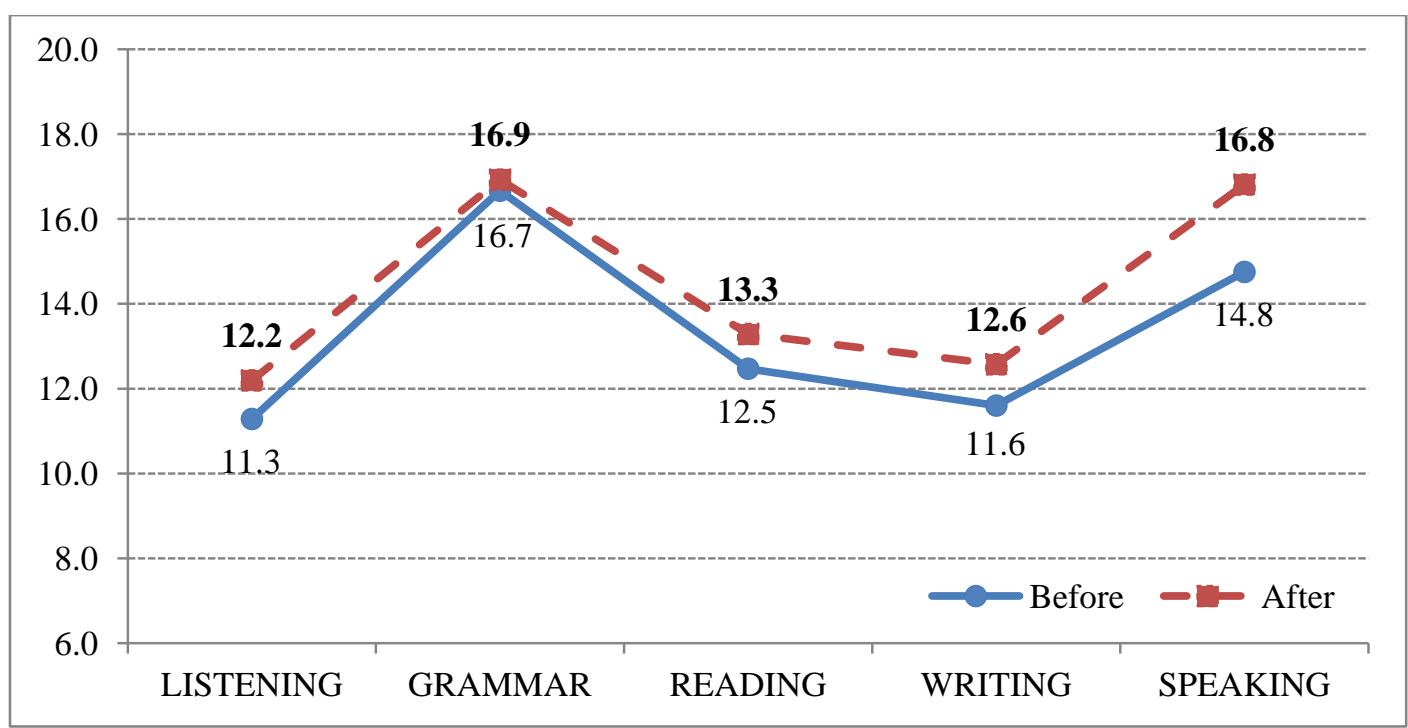

Figure 4: Increased English Skills in Teachers

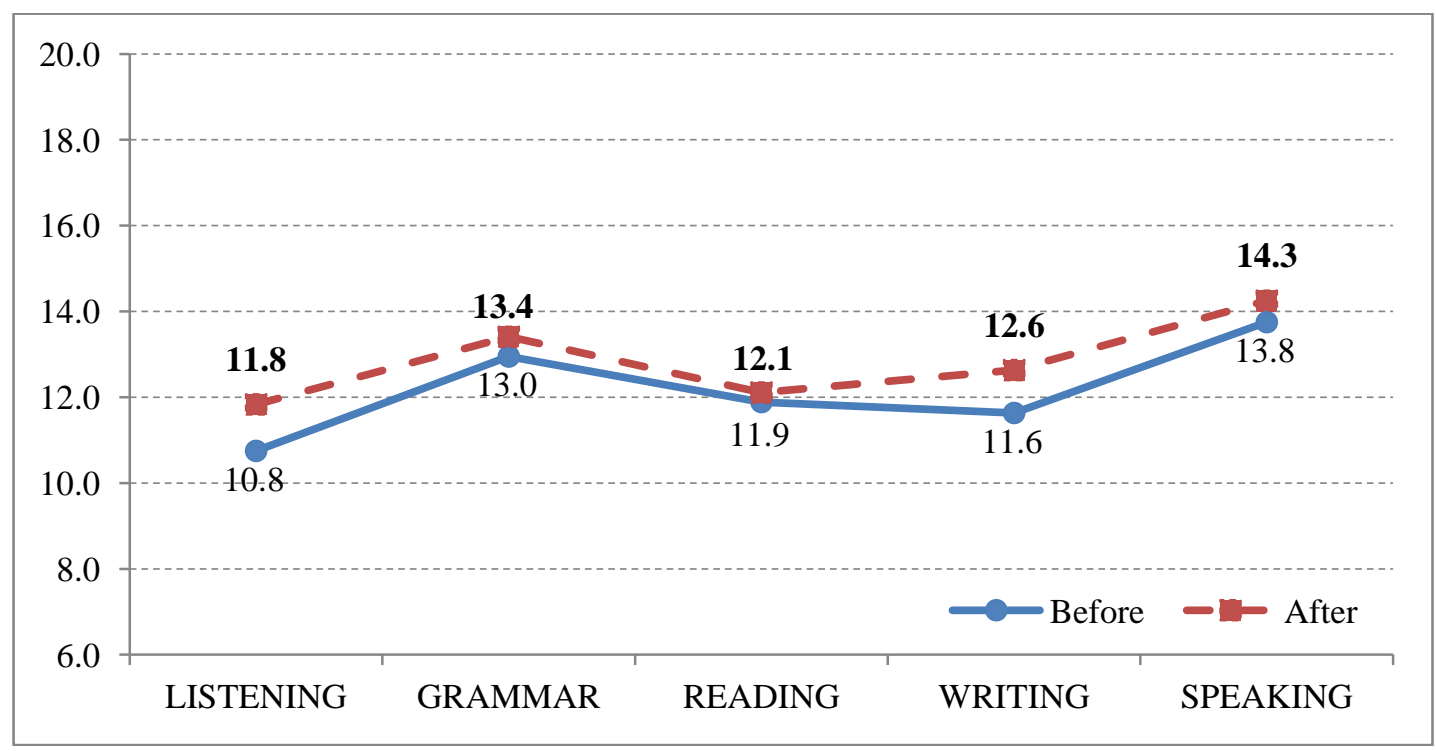

Figure 5: Increased English Skill in Employees 
The figure shows that there is an increase in English skills, before and after the one day program in English. The increase is still relatively small because the program has only been running for 6 months, but the improvement is seen to be quite significant in 5 English skills, especially speaking skills. While the grammar skill shows varied values. For regular classes the grammar ability did not change, a small increase occurred in the ICO class $(0.4)$, teachers $(0.2)$, and staff (0.4). Fact, the tahfidz class experienced a drastic decline (-2.1). This phenomenon occurs because, in the acculturation of English, the communication process prioritizes aspects of speaking, listening, reading, and writing. While the grammar aspect is not a priority. Moreover, the material studied is also related to the basic values of Islamic teachings, emphasizing the ability to speak, hear, read, and write in English. The Tahfidz class also prioritizes memorization, open grammar is a priority.

\section{DISCUSSION}

Described above is a manifestation of the results of the implementation of English-speaking culture as a strategy to shape the institutional character of Islamic education. As a sign, that internationalization which is the goal of implementing the strategy to shape the institutional character of Islamic education in schools is achieved.

According to Wayne, the purpose of communication is "to secure understanding", which means ensuring that the communicant understands the message received by him. If it can be understood and accepted, then the acceptance must be fostered (Efendi, 2017).

In this case, the principal has a large role in coaching. Forming character in schools, through "continuous coaching through modeling (teaching), teaching (teaching), and strengthening the character (reinforcing) that is good for all school members" (Widodo, 2018: 69).

The statement of the principal, as a communicator, conveyed the message, wanting to internationalize the school. The desire is conveyed to the deputy heads, teachers, staff, and students, as the communicant. All the deputy chiefs accepted the idea and then translated it into various programs. Teachers, staff, and students are also happy to actively participate in carrying out various English-language cultural programs at the school.

Strategies like this are effective, as evidenced by the understanding of the communicant and the delivery of messages well. So that English-language programs one day a week can be achieved. Various school designs, events, and special events for the acculturation of English are also well organized. Speaking Class, Vocabulary class, English Friendship Camp, English Fun Camp, Mind Empowering, Student Talent, ICO Competition, Learning Through Native, Watching Movie, English Camp in Pare, and also Summer Camp, and Extracurricular English Club held at this school, has become a school culture, a reflection of international schools.

English-speaking culture is used as a strategy to form the institutional character of Islamic education in this school is very appropriate, because all school members can work together, so that integrity, professionalism, innovation, responsibility, and example as taught by Islam are the main characters in these Islamic educational institutions. as a reflection of an international school.

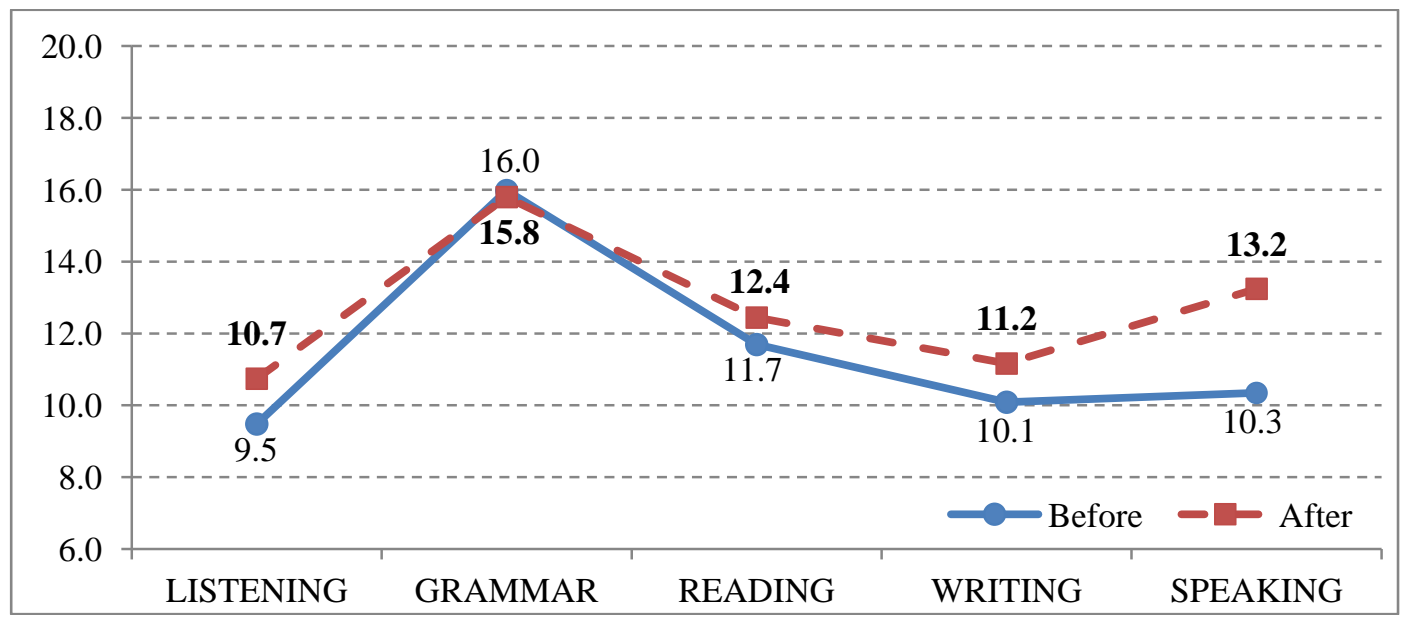

Figure 6: Increase English Skills of all Students

The figure shows an increase in all aspects of student ability, an average increase of 5.22, the highest increase in the speaking aspect, the lowest grammar aspect. However, if we look closely at each program, there will be varied grammar abilities. Regular class, Tahfidz class, and ICO class.

The average increase in English language skills is 5.23. The highest occurred in the ICO class (7.4), then regular, and finally Tahfidz. Judging from the aspect of the ability, the highest occurred in the ability to speak, all classes experienced an increase, while the grammar aspect decreased. The Tahfidz class contributed the most to the decline in Grammar aspects, the regular class did not increase (fixed), whereas the ICO class experienced an increase. This condition occurs 
besides the culture of English in this school is more oriented to the ability to speak, also Tahfidz class is more focused on memorizing the Koran, not on deepening English. A clearer picture can be seen in the following figure:

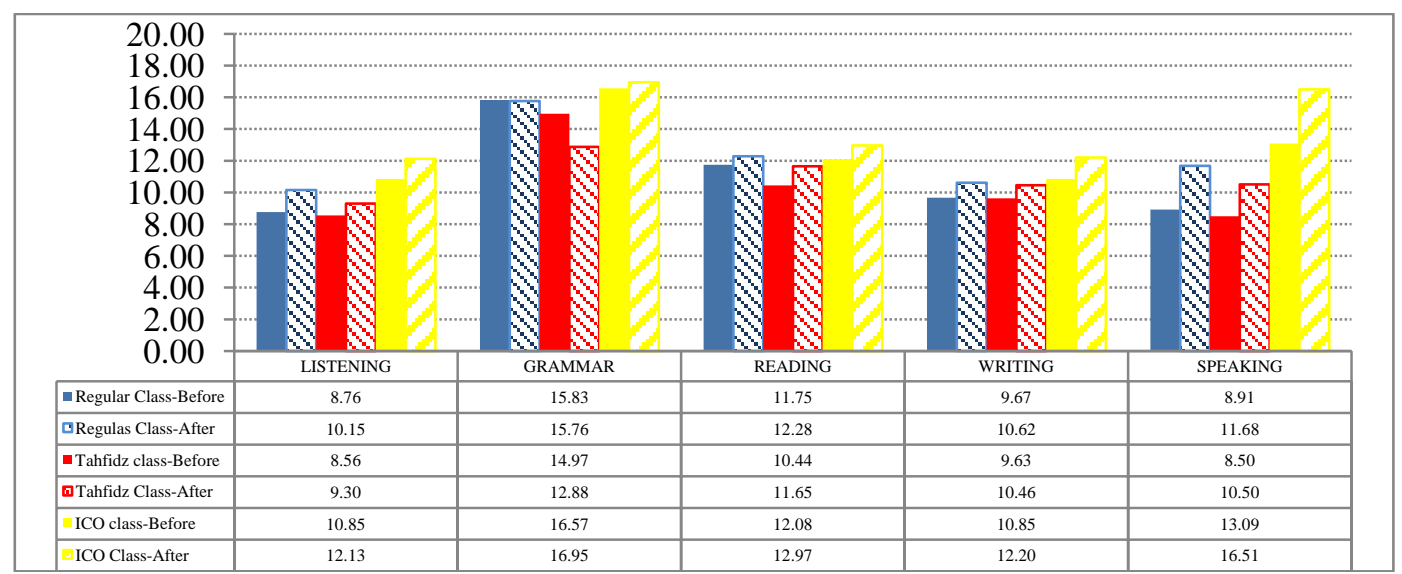

Figure 7: Comparison of English Skill in regular, tahfidz, and ICO classes

The goal of acculturating English communication is not only for students. but also for teachers and school staff. Cultivation is carried out in the hope that all school members will have English language skills. So that the internationalization of the character of Islamic educational institutions is formed. Comparison of the abilities of each school citizen can be seen in the following figure 8 :

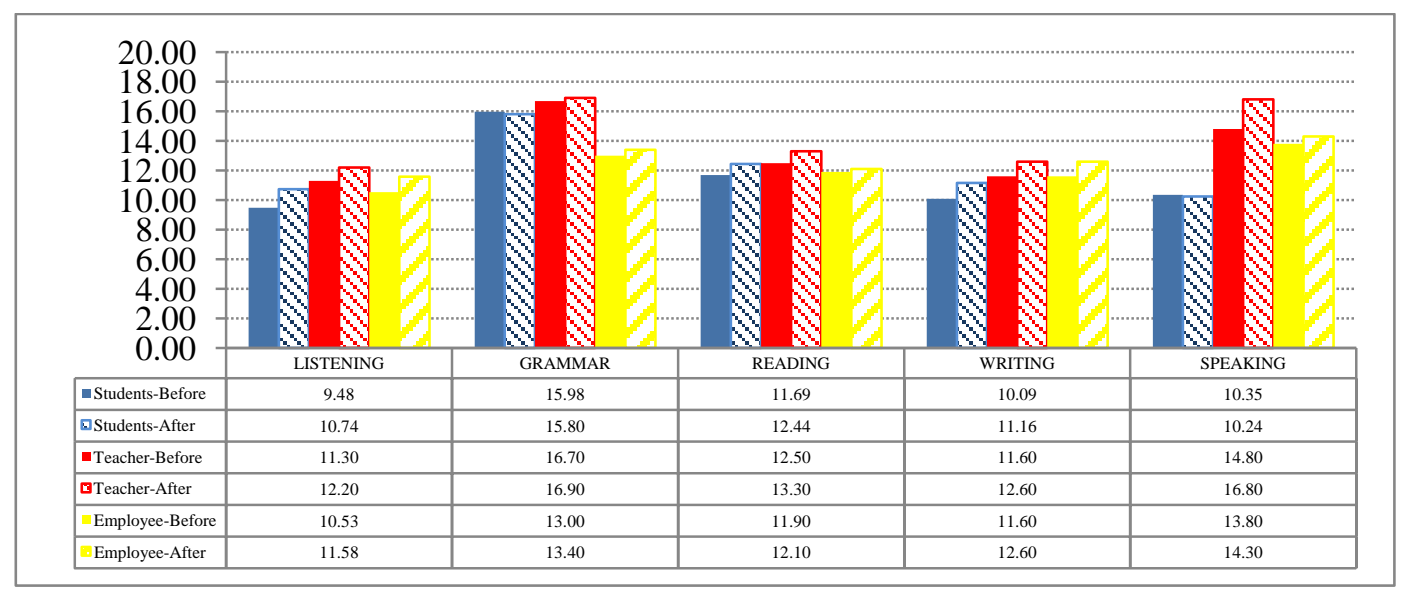

Figure 8: Comparison of English Skill for Students, Teachers, and Employees

When examined in the figure, the average increase in English language skills is 4.63. The highest increase in students, then teachers, only after those employees. Even so, the highest final score is in the teacher, after that the employee, then the student. This difference occurs, because teachers and employees already have the initial provision of higher English language skills, while acculturating English, students experience more than teachers and employees. Especially for teachers who do not teach English, only employees.

Viewed from the aspect of skills, the lowest increase in the grammar aspect (0.14), even for the average student has decreased (-18), the contribution was decreased by tahfidz classes (-2.1). While the highest increase was in the aspect of speaking ability (1.8), occurring both in students, teachers, and employees. This difference proves, the acculturation of English-language communication in this school prioritizes the ability to speak rather than grammar. The priority is courage in speaking, not in grammar so that all school members can establish communication comfortably, without being burdened by the lack of grammar. This method is by the results of Vallente's study (2020) that the feeling of being embarrassed in English for fear of being wrong is a major obstacle. Because it must be eliminated.

Most important in the acculturation of English is the presence of feelings of pleasure, not perceiving as a foreign language (Al-Ahdal \& Al-Qunayeer, 2020; Karim et al, 2020). So that it feels easier. Need the same positive response (Yusra \& Lestari, 2020), and the right emotional and socialization ties. According to Azar et al, (2020) in the process of learning English, there is no correlation between teacher intelligence with students' English proficiency. Whereas Ahmad and Millar (2020) stated the quality of students' English communication correlated with the quality of the textbooks used by the teacher. Even Gheyathaldin and Shishakly (2020) prove there is no correlation between English language proficiency with performance. Even so, at least English proficiency has a contribution to facilitate communication and access to various information, so that his insight is broader. If this continues, it will gradually encourage an increase in the performance of both individuals and institutions. 
The effectiveness of acculturation in English occurs when all school members can read and understand English well, are integrated with all activities, and are prepared thoroughly every day (Rajab and Azeebaree, 2020). This step must be done because reading comprehension is the most difficult part of English, takes more time (Elfiondri et al, 2020). This is where various strategies are needed to accelerate reading comprehension, including metacognitive, even though the results are not always the same (James \& Bulusan, 2020).

The quality of English-language communication possessed by all school members encourages an increase in the character of integrity, professionalism, innovative, exemplary, and responsible as reflected by the institution. There was an internationalization process of the institutional character of Islamic education in schools.

Table 5: The Effectiveness of Acculturation English Communication in Forming of Institutional Character of Islamic Education as an Effort to Internationalize Schools

\begin{tabular}{|c|c|c|c|}
\hline No & $\begin{array}{l}\text { Institutional } \\
\text { Character of } \\
\text { Islamic } \\
\text { Education }\end{array}$ & $\begin{array}{c}\text { Condition of Education } \\
\text { Institutional Character Before } \\
\text { Acculturation of English } \\
\text { Communication }\end{array}$ & $\begin{array}{c}\text { Achievements of Education } \\
\text { Institutional Character } \\
\text { Indicators After Acculturating } \\
\text { English Communication }\end{array}$ \\
\hline 1 & $\begin{array}{l}\text { Integrity: } \\
\text { Harmony } \\
\text { between heart, } \\
\text { mind, words, } \\
\text { and actions that } \\
\text { are good and } \\
\text { right in } \\
\text { accordance with } \\
\text { the basic } \\
\text { principles of } \\
\text { Islamic } \\
\text { teachings, } \\
\text { school rules, } \\
\text { qoidah } \\
\text { friendship, and } \\
\text { applicable laws. }\end{array}$ & $\begin{array}{l}\text { a. All unit leaders and school } \\
\text { residents have the } \\
\text { determination and willingness } \\
\text { to do good and right for the } \\
\text { progress of the school. } \\
\text { b. All unit leaders and school } \\
\text { residents think positively, } \\
\text { wisely, and wisely in carrying } \\
\text { out their duties and functions. } \\
\text { So that the institution's } \\
\text { synergy is formed, the } \\
\text { progress and development of } \\
\text { the school are achieved. } \\
\text { c. All unit leaders and school } \\
\text { residents cultivate the values } \\
\text { of Islamic teachings that are } \\
\text { shahihah, adhere to school } \\
\text { rules and code of ethics, } \\
\text { school rules, qoidah } \\
\text { organization, and legislation } \\
\text { in force in Indonesia, but } \\
\text { sometimes unconsciously } \\
\text { some individuals lack } \\
\text { compliance with school rules, } \\
\text { so schools must finish } \\
\text { immediately. So that the } \\
\text { school's image is maintained } \\
\text { and progress can be achieved. } \\
\text { d. All school leaders and } \\
\text { residents reject corruption, } \\
\text { bribery, or gratuity, besides } \\
\text { being inappropriate and } \\
\text { forbidden in Islamic } \\
\text { teachings, also because it can } \\
\text { damage the image of Islamic } \\
\text { schools and make schools not } \\
\text { develop. }\end{array}$ & $\begin{array}{l}\text { a. All unit leaders and school } \\
\text { residents have the } \\
\text { determination and } \\
\text { willingness to do good and } \\
\text { right for the progress of the } \\
\text { school, the } \\
\text { internationalization of the } \\
\text { school. } \\
\text { b. All unit leaders and school } \\
\text { members think positively, } \\
\text { wisely, and wisely in } \\
\text { carrying out their respective } \\
\text { duties and functions for the } \\
\text { progress and development } \\
\text { of international schools } \\
\text { c. All unit leaders and school } \\
\text { residents cultivate the values } \\
\text { of Islamic teachings that are } \\
\text { shahihah, adhere to school } \\
\text { rules and code of ethics, } \\
\text { school rules, qoidah } \\
\text { organization, and laws that } \\
\text { apply in Indonesia for the } \\
\text { continuation and realization } \\
\text { of international Islamic } \\
\text { schools. } \\
\text { d. All school leaders and } \\
\text { residents reject corruption, } \\
\text { bribery, or gratification, } \\
\text { besides being inappropriate } \\
\text { and forbidden in Islamic } \\
\text { teachings, also because it } \\
\text { can damage the image of } \\
\text { Islamic schools and make } \\
\text { schools undeveloped, which } \\
\text { can hinder } \\
\text { internationalization } \\
\text { schools. }\end{array}$ \\
\hline 2 & $\begin{array}{l}\text { Professionalism: } \\
\text { Work in a } \\
\text { disciplined, } \\
\text { competent, and } \\
\text { timely manner } \\
\text { with the best } \\
\text { results } \\
\text { according to the }\end{array}$ & $\begin{array}{l}\text { a. Not all unit leaders and } \\
\text { school residents have done } \\
\text { their work according to their } \\
\text { competencies, duties, and } \\
\text { functions. } \\
\text { b. Not all unit leaders and } \\
\text { school residents carry out } \\
\text { their tasks according to }\end{array}$ & $\begin{array}{l}\text { a. All unit leaders and school } \\
\text { residents carry out work } \\
\text { according to their job } \\
\text { competencies, duties, and } \\
\text { functions. } \\
\text { b. All unit leaders and school } \\
\text { residents carry out their } \\
\text { tasks according to carefully }\end{array}$ \\
\hline
\end{tabular}


goals set

carefully planned plans

c. Not all unit leaders and school residents are disciplined and are serious in their work and carrying out their duties.

d. Not all unit leaders and school residents have done the work in a measured and responsible manner.

e. Not all unit leaders and school residents carry out and complete tasks on time and following the objectives set.

f. Not all unit leaders and school residents are willing to receive rewards and punishments following the provisions in force in schools, law enforcement, and government.

3 Innovation:

Perfecting existing ones and creating new and better things. a. There are still unit leaders and the majority of school members who are not yet willing to make periodic and ongoing improvements and improvements to each of their respective functions and tasks.

b. There are still unit leaders and school residents who are closed in accepting constructive new ideas;

c. There is still a unit leader and the majority of school members who have not seriously tried to improve their competence and capacity.

d. There are still unit leaders and most school residents who have not dared to make breakthroughs and solutions in solving problems encountered while carrying out their respective functions and duties, always relying on the help of others.

e. Almost all unit leaders and school residents are not yet willing and to be able to communicate in English according to their competencies, so they have not been able to find and understand various kinds of English references to broaden their horizons to improve and develop their respective functions and tasks. And that's what planned plans

c. All unit leaders and school residents are disciplined and earnest in working and carrying out their respective duties.

d. All unit leaders and school residents carry out measured and responsible work.

e. All unit leaders and school residents carry out and complete tasks on time and following the stated objectives.

f. All unit leaders and school residents are willing to receive rewards and punishment following the provisions in force in schools, prerequisites, and government.

a. All unit leaders and the majority of school members always make regular and continuous improvements and improvements to each of their respective functions and tasks.

b. All unit leaders and school residents are open in accepting constructive new ideas;

c. All unit leaders and the majority of school residents are seriously trying to improve their competence and capacity.

d. All unit leaders and school residents dare to make breakthroughs and solutions in solving problems encountered while carrying out their respective functions and duties, while still synergizing with others.

e. All unit leaders and school residents are willing and able to communicate in English according to their competencies, can seek and understand various kinds of English references to broaden their horizons to improve and develop their respective functions and duties.

f. All unit leaders and school residents can utilize information and communication technology to work effectively and 


\begin{tabular}{|c|c|c|c|c|}
\hline & & g. & $\begin{array}{l}\text { English communication is } \\
\text { only English teachers, in a } \\
\text { small part of the time } \\
\text { teaching English in class, not } \\
\text { done outside the classroom. } \\
\text { Many unit leaders and school } \\
\text { residents have not been able } \\
\text { to take advantage of } \\
\text { information and } \\
\text { communication technology } \\
\text { at work, making it less } \\
\text { effective and efficient, and } \\
\text { nobody has even been able } \\
\text { to develop it (innovate). } \\
\text { The school network is } \\
\text { limited, local, regional level. }\end{array}$ & $\begin{array}{l}\text { efficiently, and some can } \\
\text { even develop it (innovate). } \\
\text { g. The school network is } \\
\text { becoming wider, global in } \\
\text { nature, international }\end{array}$ \\
\hline 4 & $\begin{array}{l}\text { Responsibility: } \\
\text { work } \\
\text { thoroughly and } \\
\text { consistently, be } \\
\text { responsible for } \\
\text { the various risks } \\
\text { posed, both to } \\
\text { the institution, } \\
\text { the trust, and to } \\
\text { Allah SWT. }\end{array}$ & a. & $\begin{array}{l}\text { Sometimes there are still unit } \\
\text { leaders and or school } \\
\text { residents who have not been } \\
\text { able to complete the work } \\
\text { properly and on time; } \\
\text { Sometimes there are still unit } \\
\text { leaders and or school } \\
\text { residents who are not easy to } \\
\text { admit mistakes, are less } \\
\text { willing to accept the } \\
\text { consequences, and take } \\
\text { corrective measures that } \\
\text { seem forced there are still } \\
\text { Sometimes there } \\
\text { school residents who have } \\
\text { not been able to overcome } \\
\text { the problem immediately, } \\
\text { must be helped by others. } \\
\text { Sometimes there are school } \\
\text { members who are less } \\
\text { committed to the tasks } \\
\text { assigned and carry out less } \\
\text { responsibility. }\end{array}$ & $\begin{array}{l}\text { a. All unit leaders and school } \\
\text { residents can complete the } \\
\text { work properly and on time; } \\
\text { b. All unit leaders and citizens } \\
\text { of the school dare to admit } \\
\text { mistakes, are willing to } \\
\text { accept the consequences, and } \\
\text { take corrective steps with full } \\
\text { awareness } \\
\text { c. All school members can } \\
\text { overcome the problem } \\
\text { immediately, on their efforts, } \\
\text { or with help from fellow } \\
\text { school members. } \\
\text { d. All school members are } \\
\text { committed to the tasks } \\
\text { assigned and carry out with } \\
\text { full responsibility to the } \\
\text { institution, trust, and Allah } \\
\text { SWT. }\end{array}$ \\
\hline 5 & $\begin{array}{l}\text { Exemplary: } \\
\text { Being good for } \\
\text { fellow school } \\
\text { residents and } \\
\text { other people }\end{array}$ & a. & $\begin{array}{l}\text { Sometimes there are still } \\
\text { school residents who show } \\
\text { bad character and feel } \\
\text { offended when reminded. } \\
\text { Not all school residents } \\
\text { provide services with a good } \\
\text { attitude, full of hospitality, } \\
\text { and act fairly. } \\
\text { Not all unit leaders provide } \\
\text { guidance and provide } \\
\text { guidance to subordinates and } \\
\text { colleagues, there are still } \\
\text { leaders who seem to dislike } \\
\text { receiving input from } \\
\text { subordinates. } \\
\text { Not all school residents are } \\
\text { willing to provide guidance } \\
\text { and direction to their peers, } \\
\text { there are still those who are } \\
\text { indifferent to others, and even } \\
\text { easily offended when there is } \\
\text { a reminder. } \\
\text { Not all residents have done a }\end{array}$ & $\begin{array}{l}\text { a. All school members showed } \\
\text { good morals and we're very } \\
\text { happy when someone } \\
\text { reminded them. } \\
\text { b. All school residents provide } \\
\text { services with a good attitude, } \\
\text { full of hospitality, and act } \\
\text { fairly. } \\
\text { c. Each unit leader conducts } \\
\text { guidance and gives direction } \\
\text { to subordinates and peers, } \\
\text { and is willing to accept input } \\
\text { from subordinates. } \\
\text { d. All school members are } \\
\text { willing to provide mutual } \\
\text { guidance and direction to } \\
\text { their peers, care for others, } \\
\text { and are willing to accept } \\
\text { input willingly. } \\
\text { e. All residents do a good job } \\
\text { starting from themselves if } \\
\text { anyone makes a mistake, they } \\
\text { are willing to remind. }\end{array}$ \\
\hline
\end{tabular}


good job starting from

themselves, there are still

those who always find fault

with others

If we look at various indicators of the institutional character of Islamic education in the aspects of integrity, professionalism, innovation, responsibility, and absence in the table above, after stipulating the obligation to acculturation English communication, it appears that the increase in positive character is more likely to occur in the innovative character, professionalism, then responsibility and exemplary, As for the character of integrity there is only an increase in the indicator of compliance with the prevailing rules and regulations.

The small increase in the integrity indicator occurred, because previously the institutional integrity was already strong, it could even be started from the beginning very well. One indicator of high integrity can be seen in the level of discipline of students, teachers, and day-to-day employees at school before and after English language obligations are established.

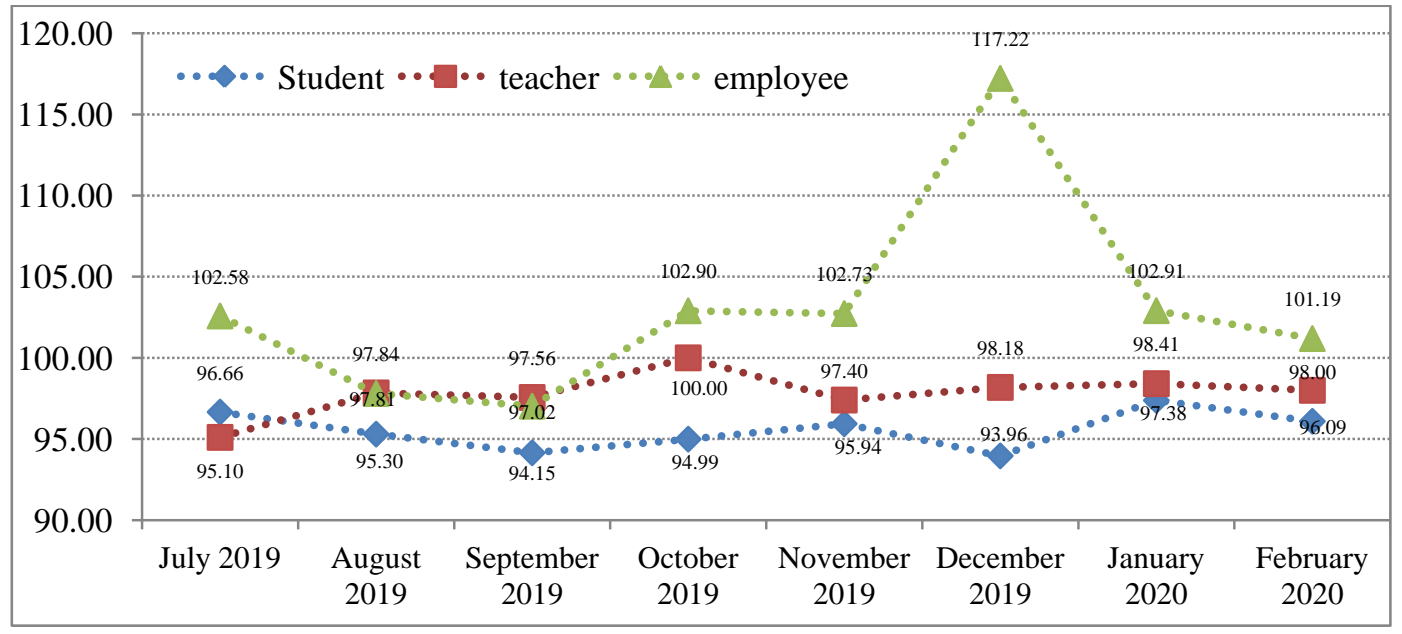

Figure 9: Comparison of the level of discipline for students, teachers, and employees before (July-Agust) and after (SepFeb) the stipulation of Speaking English obligations.

The character of integrity in schools has been formed a long time ago, before the policy on the obligation to accustom English communication. Fact, integrity became the priority when the school was founded, especially integrity in carrying out the values of Islamic teachings that are shahihah, integrity to the institution, and the progress of the school, as well as integrity to the conditions in which the school was founded and shelter.

The character of integrity is used as the main basis in recruiting new staff, teachers, and staff, as well as school leaders. The next consideration is professionalism, innovation, responsibility, and example. Integrity is also a priority in the development of leaders, teachers, employees, students, and parents of students. With this integrity, togetherness can be formed, school progress can be achieved despite various challenges faced. School members also feel comfortable, measurable performance, even though the welfare received is not following the minimum standard set by the government, there is also a proportional welfare distribution between leaders and employees. If there is a surplus of school income, there is no increase in salary, and if there is a proportional adjustment to inflation, priorities for the development of institutions, infrastructure, and various activities, and partly for the benefit of religious propaganda.

With integrity, a sense of brotherhood is maintained, solidarity among people is formed, responsibility for the task also cannot be doubted. Such conditions are the main capital for the sustainability and progress of Islamic schools.

The integrity that has been built into an individual character, develops into the character of an institution, encourages teachers and employees who can work professionally, oriented to productivity and quality of work, not to expect to get an increase in welfare guarantees from the institution.

The sincere factors that encourage synergy, professionalism, innovation, responsibility, and role models are not noticed by the research of Maksum et al. and Basyit. Maksum et al (2020) are more interested in seeing democracy as a typical culture of Islamic education. Basyit only expressed internal awareness of designing superior education systems, in addition to external factors, namely the decline in the process and results of public school education, skepticism in the process and results of pesantren and madrasa education, increased economic capability, and government support in the autonomy of private education and "internationalization" of all levels of education in Indonesia (Basyit, 2019: 27). Though sincere because of Allah SWT. be the most determining factor. As Sivasubramaniam \& Hayhoe's research, (2018), in various developed countries, religious motives and spirituality are very important. This sincerity encourages professional work, even when there is an innovation effort, even though it is still limited, and is carried out with full responsibility. Can be a role model for others. 
The sincere factor also makes this educational institution still exist, able to serve the entire economic strata of society with good management, according to accounting standards. This fact shows evidence that is different from the research Puruwita \& Murdayanti (2018) who found financial management does not match accounting standards. Through good accounting management, the school's finances have become healthy. At the same time rejecting the assumption of some people who state, that schools with international furniture, the costs are high. So that only those who have an economic status above can register (Ali, 2020).

With the acculturation of English communication, the ability to speak English of all school residents increases. The ability to speak English of each member of the school becomes a tool as well as capital for the development of professional character, innovation, responsibility, and the existence that has been formed before. So that it becomes an international standard school.

The ability to read and understand various references in English, making the insights of every school citizen develop, professionalism at work is also more perfect. Managerial innovations and various things related to learning can be done more. The integrity of the faith that is supported by the ability to speak English makes the innovations that are carried out truly accountable can be a reference. Further consequences, because a lot of innovation is done, through responsible professional work, it becomes a model school.

The ability to write English for every school member encourages the publication of various innovations and references in English. Existing documents are widely distributed through information media and telecommunications, which can be accessed from various regions. Likewise, the ability to hear and speak English, making school residents able to communicate with various other citizens, the relationship becomes wider.

School residents are also accustomed to utilizing information technology (Hermanto, Kusnanto, \& Supangat, 2018) and social media wisely and responsibly, conveying information proportionally. This character is very different from the findings of Samatan, Fatoni, and Murtiasih (2020). Social media is often used disproportionately.

In other words, the policy of acculturating English-language communication effectively encourages the internationalization of the institutional character of Islamic education; if this continues, it will truly become an international Islamic school.

\section{CONCLUSIONS AND IMPLICATIONS}

The strategy of acculturating English is effective for improving the English language skills of school members so that the internationalization of the character of Islamic education institutions is formed.

The culture of English communication is used as a strategy to form the character of Islamic education institutions to internationalize the expected future school. This strategy is carried out by the steps: getting to know the audience through a coordination meeting of all teachers and employees, composing messages containing themes and objectives of the message of civilizing English in schools, establishing methods of repeating messages so that audiences are always reminded and implementing them, and using media notice in several places and face to face through meetings held. The acculturation of English communication is an effective strategy in realizing the character of international standard Islamic education institutions, which is reflected in the habit of English language through a one day program in English, procurement of the English area.

The character of international standard Islamic education institutions, manifests in the habit of English language, in the form of the implementation of one day program in English, English area, Up-grading of students through special events, the existence of notice in every school and school area. Being in the form of attitudes, behaviors, insights, creations, and innovative works of teachers, employees, and students who are more open and competitive. His various works and innovations are published, competed, and juxtaposed on the international scene.

This research found a prototype of the character of international standard Islamic education institutions, namely institutions that have integrity, professionalism, innovation, role models and responsibilities, as well as high competitiveness in the international arena. That by acculturating English language communication has succeeded in shaping the character of a progressive Islamic education institution, ready to compete in the international arena. The spirit of internationalization is formed into an institutional character of Islamic education.

The strategy of forming the character of Islamic education institutions through English communication if it continues to be cultivated and developed, makes the existence of institutions stronger, even developing rapidly. The trust of various elements of the surrounding community, regional, national, and even international for this school will also occur so that the existence of the institution continues to develop.

\section{DECLARATION OF INTEREST STATEMENT}

All data is collected through direct observation in schools and interviews with leaders, vice leaders, and some teachers, staff, and students directly so that it is subjective. As for the English language assessment documents obtained directly from the English teacher team, the second researcher was involved in testing. Teacher, staff, and student attendance data were obtained from school staffing, the study did not record attendance alone. The identity of respondents is anonymous 
and only used for research purposes. Data is provided at a personal request. Furthermore, the authors declare that there is no funding or conflicts of interest in this work.

\section{CONSTRUCTION OF WRITERS TOGETHER}

The first and second authors together formulated the research design, discussed the process and interim research results, analyzed, and made a final research report. The first author is responsible for the entire contents of the article, especially looking for references that are relevant, compile and analyze into articles, while the second author is responsible for the accuracy of data collection and translation to English.

\section{REFERENCES}

1. Ahmad, Hamidi. Millar, Roberet McColl. (2020). Reviewing Definitional Ambiguities and Significance of Text Authenticity in English Language Teaching. Humanities \& Social Sciences Reviews, 8 (4), 1-9. https://doi.org/10.18510/hssr.2020.841

2. Al-Ahdal, Arif Ahmed Mohammed Hassan. \& Al-Qunayeer, Huda Suleiman. (2020). A Socio-Linguistic Study of Arab College Students' Attitudes and Judgements Towards World Englishes. The Asian ESP Journal, 16 (1), 55-69. Retrieved from https://www.asian-esp-journal.com/2020/volume-16-issue-1-1-february-2020

3. Al-Ahdal, Arif Ahmed Mohammed Hassan. (2020). Code Mixing in Arabic conversations of college students: A Sociolinguistic Study of attitudes to switching to English. The Asian ESP Journal, 16 (1), 06-19. Retrieved from https://www.asian-esp-journal.com/2020/volume-16-issue-1-1-february-2020

4. Ali, Marpuji. (2020). Muhammadiyah di Tengah Isu Dunia Islam Kontemporer: Refleksi untuk Internasionalisasi. Jurnal Muhammadiyah Studies, 1(1), 16-29. https://doi.org/10.22219/jms.v1i1.11406

5. Ali, Lukman. (2005). Kamus besar bahasa Indonesia. Jakarta: Balai Pustaka.

6. Anshori, Isa. (2018). Melacak State of The Art Fenomenologi dalam Kajian Ilmu-Ilmu Sosial. Halaqa: Islamic Education Journal, 2(2), 165. https://doi.org/10.21070/halaqa.v2i2.1814

7. Anshori, Isa. (2017). Penguatan Pendidikan Karakter di Madrasah. Halaqa: Islamic Education Journal, 1(2), 63-74. https://doi.org/10.21070/halaqa.v1i2.1243

8. Anshori, Isa. (2018). Penerapan Nilai Budaya Kerja : Peluang dan Tantangan Bagi Peningkatan Kinerja Madrasah. Cendekia: Jurnal Pendidikan dan Humaniora, 2 (3), 191-201. Retrieved from http://ejournal.man1lamongan.sch.id/index.php/cendekia/article/view/1

9. Azar, Ali Sorayyaei. Yi, Yap Pei \& Azhar, Nur Adzdzin. (2020). The Impact of Malaysian Education and Social Science Lecturers' Trait Emotional Intelligence and Classroom Discourse on Students' Comprehension of Learned Jargons. Asian EFL Journal. 27 (2), 48-83. Retrieved from https://www.asian-efljournal.com/monthly-editions-new/2020-monthly-editions/volume-27-issue-2-3-april-2020/

10. Basyit, Abdul. (2019). Madrasah dan sekolah Islam Elit di Indonesia : Model Pembelajaran Kooperatif Perspektif Al-Qur'an. Rausyan Fikr, 15 (1). 27-38. Retrieved from http://jurnal.umt.ac.id/index.php/rf/article/view/1366

11. Baroroh, Hanik. (2018). Manajemen Pendidikan Nilai-Nilai Multikultural dalam Pembentukan Karakter Religius Siswa di MAN Yogyakarta III tahun Pelajaran 2016/2017. Indonesian Journal of Islamic Educational Management. 1 (2), 67-87. https://doi.org/10.24014/ijiem.v1i2.6623

12. Badke, M. R., Barbieri, R. L., \& Martorell-Poveda, M. A. (2018). Internationalization of Brazilian nursing: Doctor sandwich in the Catalonia region-Spain. Texto e Contexto Enfermagem, 27(1). https://doi.org/10.1590/0104-07072018003620016

13. Badudu, J.S. dan Sutan Muhammad Zain. . (1996). Kamus Umum Bahasa Indonesia . Jakarta: Pustaka Sinar Harapan.

14. Binangkit, Intan Diane. \& Siregar, Dede Iskandar.(2020). Internasionalisasi dan Reformasi Perguruan Tinggi: Studi Kasus Pada Lembaga Pendidikan Tinggi Muhammadiyah. Jurnal Dinamika Manajemen Pendidikan (JDMP), 4 (2), 131-138. https://doi.org/10.26740/jdmp.v4n2.p131-138

15. Chudzaifah, I. (2018). Tantangan Pondok Pesantren dalam Menghadapi Era Bonus Demografi. Al-Riwayah: Jurnal Kependidikan, 10(2), 409-434. https://doi.org/10.32489/al-riwayah.168

16. Cintra, P. R., da Silva, M. D., \& Furnival, A. C. (2020). Use of English as a strategy for the internationalization of scientific production in Applied Social Sciences: a case study of SciELO Brazil. EM QUESTAO, 26(1), 17 41. https://doi.org/10.19132/1808-5245261.17-41

17. Darmanto. (2020). The Roles of a Native English Speaker Teacher (NEST) on the Students Motivation in Learning English: A Case Study at SMAN 2 Sumbawa Besar. TESOL International Journal. 15 (1), 93-99. Retrieved from https://www.elejournals.com/tesol-journal/tij-2020/tesol-international-journal-volume-15-issue$1-2020 /$

18. David, Fred R. (2006). Manajemen Strategis Konsep. Jakarta: Salemba Empat, 2006.

19. Effendy, Uchajana Onong. (2017). Ilmu Komunikasi Teori dan Praktek. Bandung: Remaja Rosdakarya

20. Effendy, Uchajana Onong. (2014). Dinamika Komunikasi. Bandung: Remaja Rosdakarya 
21. Elfiondri. Kasim, Usman. Mustafa, Faisal \& Putra, Tomi Mandala. (2020). Reading Comprehension in the TOEFL PBT: Which Sub-Skill deserves more Intensive Training? TESOL International Journal, 15 (1), 53-64. https://www.elejournals.com/tesol-journal/tij-2020/tesol-international-journal-volume-15-issue-1-2020/

22. Evananda, Febrina. Bafadal, Ibrahim. \& Sobri, Ahmad Yusuf. (2018). Studi Kasus Implementasi Pendidikan Karakter pada Sekolah Dolan. Jurnal Administrasi dan Manajemen Pendidikan, 1(3), 255-262. https://doi.org/10.17977/um027v1i32018p252

23. Fawaid, Moh Mansyur. (2017). Implementasi Tata Tertib Sekolah dalam Menngkatkan Karakter Kedisiplinan Siswa. Jurnal Civic Hukum, 2(1), 9-19. https://doi.org/10.22219/jch.v2i1.9899

24. Gheyathaldin, Lilian.\& Shishakly, Rima. (2020). Impact of English Language Proficiency on the Academic Performance of Business Students. The Asian ESP Journal, 16 (2), 245-272. Retrieved from https://www.asianesp-journal.com/2020/volume-16-issue-2-1-april-2020/

25. Halmar, Mustopa. (2012). Metode Komprehensif dalam Pendidikan Karakter. Majalah Ilmiah Sultan Agung, 50 (128), 1. Retrieved from http://jurnal.unissula.ac.id/index.php/majalahilmiahsultanagung/article/view/75

26. Hariyanto, Hariyanto. \& Jahiban, Mursini. (2019). Strategi Guru PPKn Dalam Penguatan Karakter Siswa SMPN 2 Mataram. Jurnal Pendidikan Sosial Keberagaman, 6(1), 1-17. https://doi.org/10.29303/juridiksiam.v6i1.85

27. Heriansyah, H. (2014). The Impacts of Internationalization and Globalization on Educational Context. Journal of Education and Learning (EduLearn), 8(2), 164. https://doi.org/10.11591/edulearn.v8i2.218

28. Hermanto, A., Kusnanto, G., \& Supangat. (2018). The design of IT development based on EA model for islamic boarding school. In Proceedings of the 3rd International Conference on Informatics and Computing, ICIC 2018. Institute of Electrical and Electronics Engineers Inc. https://doi.org/10.1109/IAC.2018.8780460

29. Hidayatullah, Romi. Muhardini, Sintayana. \& Haifaturrahman. (2017). Pembelajaran Inovatif untuk Menanamkan Nilai-Nilai Karakter pada Siswa Sekolah Dasar (Studi Meta-Sintesis). Prosiding, Seminar Nasional Pendidik dan Pengembang Pendidikan Indonesia dengan Tema "Membangun Generasi Berkarakter Melalui Pembelajaran Inovatif". Aula Handayani IKIP Mataram 14 Oktober, 486-494. Retrieved from http://ejournal.mandalanursa.org/index.php/Semnas/article/view/284

30. Irwan, I., \& Mahmud, M. (2017). Strategic Management System as The Internationalization Policy of Indonesian Islamic Higher Education. Atlantis Press. https://doi.org/10.2991/yicemap-17.2017.26

31. James, Haydee Daguay, \& Bulusan, Ferdinand. (2020). Metacognitive Strategies on Reading English Texts of ESL Freshmen: A Sequential Explanatory Mixed Design. TESOL International Journal. 15 (1), 20-30. Retrieved from https://www.elejournals.com/tesol-journal/tij-2020/tesol-international-journal-volume-15-issue$1-2020 /$

32. Javier, Cristina Lamsen. (2020). The Shift towards New Teaching Modality: Examining the Attitude and Technological Competence among Language Teachers teaching Filipin. The Asian ESP Journal, 16 (2), 210224. Volume 16 Edisi 2.1 April 2020. https://www.asian-esp-journal.com/2020/volume-16-issue-2-1-april2020/

33. Johnson, K. (2020). 21st Century International Higher Education Hotspots. Journal of International Students, 10(1), v-viii. https://doi.org/10.32674/jis.v10i1.1851

34. Karim, Sayit Abdul. Sulistyo, Gunadi Harry. Rachmajanti, Sri \& Suryati, Nunung.(2020). Exploring EFL Teachers' Beliefs about English Language Learning and Teaching: Evidence from Indonesia Context. Asian EFL Journal. 27 (2), 227-246. Retrieved from https://www.asian-efl-journal.com/monthly-editions-new/2020monthly-editions/volume-27-issue-2-3-april-2020/

35. Karolina, Asri. (2017). Rekonstruksi Pendidikan Islam Berbasis Pembentukan Karakter: Dari Konsep Menuju Internalisasi Nilai-Nilai Al-Qur'an. Jurnal Penelitian, 11 (2), 237-266. https://doi.org/10.21043/jupe.v11i2.2841

36. Khan, M. A., \& Ebner, N. (2017). The self-internationalization model (sim) versus conventional internationalization models (cims) of the institutions of higher education: A preliminary insight from management perspectives. In Proceedings of the 30th International Business Information Management Association Conference, IBIMA 2017 - Vision 2020: Sustainable Economic development, Innovation Management, and Global Growth, Vol. 2017-January, 1191-1203. https://doi.org/10.15549/jeecar.v5i1.189

37. Khan, Firdouse Rahman. (2020). PASSION-BASED TEACHING IN CLASSROOM: AN ANALYSIS USING SEMPLS APPROACH, Humanities \& Social Sciences Reviews, 8 (3), pp 562-573. https://doi.org/10.18510/hssr.2020.8361

38. Kurnia, Septiawan Santana. Othman, Siti Suriani. Firmansyah. \& Kuswarno, Engkus. (2020). Fact Searching in Investigative Reporting in Indonesia: A Case Study of Tempo and Gatra Magazines. Malaysian Journal of Communication, 36 (1), 1-19. https://doi.org/10.17576/JKMJC-2020-3601-17

39. Latupapua, Falantino Eryk. Salamor, Lisye. Monaten, Yessa Gracia. \& Tuhepaly, Fadly. (2019). Implementasi Teks Cerita Rakyat Maluku sebagai Bahan Ajar bahasa Indonesia terkait Nilai Antikorupsi di SMA Negeri 1 Amahai, Kecamatan Amahai, Kabupaten Maluku Tengah. ARBITRER: Jurnal Pendidikan Bahasa dan Sastra Indonesia, 1 (1), 1-6. https://doi.org/10.30598/arbitrervol1no1hlm01-16 
40. Maksum, Muh. Nur Rochim. Asy’arie, Musa. \& Aly, Abdullah. (2020). Democracy Education Through the Development of Pesantren Culture. Humanities \& Social Sciences Reviews, 8 (4), 10-17. https://doi.org/10.18510/hssr.2020.842

41. Masrizal, Fata, Ika Apriani \& Erdiana, Nira. (2020). Investigating In-Service Teachers' Perceptions on Online and Autonomous Learning. Humanities \& Social Sciences Reviews, 8 (3), pp 456-465. https://doi.org/10.18510/hssr.2020.8349

42. Moeleong, Lexy J. (2011). Metodologi Penelitian Kualitatif. Bandung,: Rosda Karya.

43. Muhajir, Noeng. (1996). Metode Penelitian Kualitatif.Yogyakarta: Rake Paskin.

44. Nurhamidi. (2015). Strategi Komunikasi Kepala Sekolah Madrasah Berprestasi dalam Pengembangan Madrasah Ibtidaiyah:Studi Kasus di MI Muhammadiyah Sarangrejo Kulonprojo. Al-Bidayah: Jurnal Pendidikan Dasar Islam, 7(2), 104-124. Retrieved from https://www.neliti.com/id/publications/284588/strategikomunikasi-kepala-madrasah-berprestasi-dalam-pengembangan-madrasah-ibti

45. Nursalam. (2020). Glocal Vision to Deconstruct Internationalization in Indonesian Higher Education. JSSER: Journal of Social Studies Education Research, 11(1), 137-152. Retrieved from https://jsser.org/index.php/jsser/article/view/1931

46. Puruwita, D., \& Murdayanti, Y. (2018). Measuring financial management in Islamic educational institutions in Indonesia. In Proceedings of the 32nd International Business Information Management Association Conference, IBIMA 2018 - Vision 2020: Sustainable Economic Development and Application of Innovation Management from Regional expansion to Global Growth (pp. 7120-7130).

47. Qomaro, G. W. (2019). Pesantren As Halal Tourism Co-Branding: Halal Industry For Sustainable Development Goals. Maqdis : Jurnal Kajian Ekonomi Islam, 4(1), 11. https://doi.org/10.15548/maqdis.v4i1.206

48. Rajab, Farhad Mohammad \& Alzeebaree, Yaseen. (2020). Effectiveness of English Language in a Globalized World: EFL Teachers of Duhok Universit. Asian EFL Journal. 27 (2).3 April 2020, 38-47. Retrieved from https://www.asian-efl-journal.com/monthly-editions-new/2020-monthly-editions/volume-27-issue-2-3-april$\underline{2020 /}$

49. Rizal, Syaiful. \& Munip, Abdul. (2017). Strategi Guru Kelas dalam Mumbuhkan Nilai-nilai Karakter Pada Peserta Didik (Study Kasus : SDN Pondok Dalem 01 Semboro dan MI Fathus Salafi Ajung Jember). Al Ibtida: Jurnal Pendidikan Guru MI, 4(1), 45-60. https://doi.org/10.24235/al.ibtida.snj.v4i1.1462

50. Sabri. Ahmad. (2020). Trends of "Tahfidz House" Program in Early Childhood Education. JPUD - Jurnal Pendidikan Usia Dini, 14(1), 78-93. https://doi.org/10.21009/JPUD.141.06

51. Samatan, Nuriyti. Fatoni, Ahmad. \& Murtiasih, Sri. (2020). Disaster Communication Patterns and Behaviors on Social Media: A Study Social Network \#Banjir2020 on Twitter. Humanities \& Social Sciences Reviews, 8 (4), 27-36. https://doi.org/10.18510/hssr.2020.844

52. Sivasubramaniam, M., \& Hayhoe, R. (2018). Religion and Education: Comparative and International Perspectives. Oxford Studies in Comparative Education. Oxford Studies in Comparative Education Series. Symposium Books. https://doi.org/10.15730/books.101

53. Surachman, Puri Rahmi. Wiksana, Wiki Angga. (2019). Strategi Komunikasi Kepala Sekolah dalam Mensosialisasikan Program Kerjanya Kepada Guru. Prosiding Manajemen Komunikasi, Seminar Penelitian Civitas Akademika Universitas Islam Bandung, 5(2), 883-888. Retrieved from http://karyailmiah.unisba.ac.id/index.php/mankom/article/view/19137

54. Yani, Ahmad. Khaeriyah, Ery. \& Ulfah, Maulidiyah. (2017). Implementasi Islamic Parenting dalam Membentuk Karakter Anak Usia Dini di RA At-Taqwa Kota Cirebon. AWLADY : Jurnal Pendidikan Anak, 3(1), 153-174. https://doi.org/10.24235/awlady.v3i1.1464

55. Yusra, Kamaludin. \& Lestari, Yuni Budi. (2020). Local Responses to a Regional Policy: Insights from English as a Working Language in ASEAN Countries. The Asian ESP Journal, 16 (2), 309-334. Retrieved from https://www.asian-esp-journal.com/2020/volume-16-issue-2-1-april-2020/

56. Vallente, John Paul C. (2020). Sources of embarrassment or empowerment? Oral Feedback Strategies in English Language Teaching Classrooms. TESOL International Journal, 15 (1), 31-32. https://www.elejournals.com/tesol-journal/tij-2020/tesol-international-journal-volume-15-issue-1-2020/

57. Vranes, A., \& Markovic, L. (2017). Study Programs for Joints Degrees-Theoretical and Empirical Findings of The University of Belgrade. In ICERI2017 Proceedings, IATED, Vol. 1, 7659-7665. IATED. https://doi.org/10.21125/iceri.2017.2035

58. Widodo, Hendro. (2018). Strategi Kepala Sekolah dalam Mengembangkan Pendidikan karakter di Sekolah Dasar Muhammadiyah Sleman. Metodik Didaktik: Jurnal Pendidikan ke-SD-an, 13 (2), 69-80. https://doi.org/10.17509/md.v13i2.8162

59. Zuhdi, Asiqin. (2018). Dampak Rintisan Internasionalisasi Pendidikan Tinggi di UIN Walisongo Semarang. LITERASI, IX (2), 124-147. https://doi.org/10.21927/literasi.2018.9(2).124-147 